\title{
Czynnik ludzki a skuteczność ochrony przeciwporażeniowej użytkowników prądu elektrycznego w obiektach budowlanych
}

\author{
Andrzej Sumorek \\ Katedra Mechaniki Budowli, Wydziat Budownictwa i Architektury, Politechnika Lubelska, \\ e-mail:a.sumorek@pollub.pl
}

Streszczenie: Opracowanie prezentuje środki ochrony przeciwporażeniowej stosowane w instalacjach elektrycznych niskiego napięcia w aspekcie ich nieskuteczności w odniesieniu do wybranych sytuacji. W pierwszej części artykułu scharakteryzowano powody zapobiegania przepływowi prądu elektrycznego przez organizm ludzki. Jednocześnie opisano sposoby zapobiegania niekorzystnemu oddziaływaniu prądu na użytkownika urządzeń elektrycznych w instalacjach o napięciu do $1 \mathrm{kV}$. Końcowa część pracy zawiera zestawienie przypadków, w których zastosowane środki stają się nieskuteczne oraz analizę przyczyn powstawania wypadków.

Słowa kluczowe: ochrona przeciwporażeniowa, instalacja elektryczna, wypadki przy pracy.

\section{Wstęp. Negatywne oddziaływanie prądu elektrycznego na organizm czlowieka}

Pierwsze wzmianki dotyczące oddziaływania energii elektrycznej na organizmy żywe datuje się na XVIII wiek. Jednak dopiero upowszechnienie urządzeń elektrycznych w XIX wieku dało początek badaniom nad wpływem prądu elektrycznego na organizm ludzki. Za przełomową datę można uznać rok 1887, w którym opisano przypadek śmiertelnego porażenia w wyniku wypadku zawiązanego z użytkowaniem urządzenia elektrycznego. Badania prowadzone w końcu XIX i na początku XX wieku szły w kierunku badania impedancji ciała człowieka ze szczególnym uwzględnieniem skóry, badania wpływu napięcia i częstotliwości prądu rażeniowego oraz opisywania rzeczywistych przypadków porażeń. Kolejnym kierunkiem testów były badania związane z migotaniem komór serca wywołanym prądem elektrycznym oraz samym wyczuwaniem przepływu prądu przez ludzi. W latach trzydziestych dwudziestego wieku zaczęto poszukiwać zależności czasu i natężenia prądu przy analizie oddziaływania prądu na organizmy żywe. Międzynarodowa Komisja Elektrotechniki (IEC) po raz pierwszy opublikowała tego typu raport w roku 1974. Zamieszczona w niniejszej pracy ilustracja „Charakterystyki oddziaływania prądu przemiennego na organizm człowieka przy przepływie prądu pomiędzy lewą ręką i stopami” pochodzi z raportu Międzynarodowej Komisja Elektrotechniki z roku 2005 [1].

Istnieje wiele przypadków świadomego i celowego stosowania przepływu prądu elektrycznego przez organizm ludzki. Ten rodzaj działania stosuje się w rehabilitacji. W elektrostymulacji, mięśnie z uszkodzonymi połączeniami nerwowymi mogą być pobudzane zewnętrznymi impulsami elektrycznymi. Prądy diadynamiczne mogą poprawiać ukrwienie tkanek i powodować szybszą regenerację mięśni. Prądy interferencyjne i galwaniczne mogą 
obniżać napięcie mięśniowe wspomagać proces kostnienia [2]. Z drugiej strony powszechnie stosowana terapia biorezonansowa nie znajduje potwierdzenia $\mathrm{w}$ dowodach naukowych [3]. W gabinetach kosmetycznych przepływ prądu elektrycznego przez skórę ma zwężać rozszerzone pory, zmiękczać skórę (galwanizacja), wprowadzać do tkanek skóry jony metali (jonoforeza), masować skórę za pomocą prądów wysokiej częstotliwości (d’arsonwalizacja). Wymuszenie przepływu prądu stałego pochodzącego z defibrylatora likwiduje zaburzenia pracy serca (migotanie komór) i często jest jedyną metodą wznowienia pracy układu krążenia [4].

Wyżej opisane przypadki dotyczą sytuacji, w których przez organizm ludzki przepływa prąd o kontrolowanym natężeniu, kształcie, w znanym czasie i po kontrolowanej drodze. Można stwierdzić, że kiedy tracona jest kontrola nad parametrami przepływu prądu występuje zjawisko porażenia prądem elektrycznym.

Przy analizie zjawiska porażenia, człowiek traktowany jest jako odbiornik elektryczny o impedancji zależnej od drogi przepływu prądu (np. lewa ręka - prawa ręka, lewa ręka stopa, ...), wilgotności naskórka, częstotliwości prądu, siły docisku elektrod, wartości napięcia, czasu trwania rażenia [5,6]. Bardziej ściśle, porażenie prądem elektrycznym występuje w sytuacji, w której człowiek dotknie 2 punktów o różnych potencjałach elektrycznych. Następstwem dotknięcia jest przepływ prądu rażeniowego [6]. Ciało ludzkie staje się wtedy elementem obwodu elektrycznego [5]. Sposób oddziaływania prądu przemiennego o częstotliwości z zakresu 15-100 Hz ilustruje Rys. 1 [7].

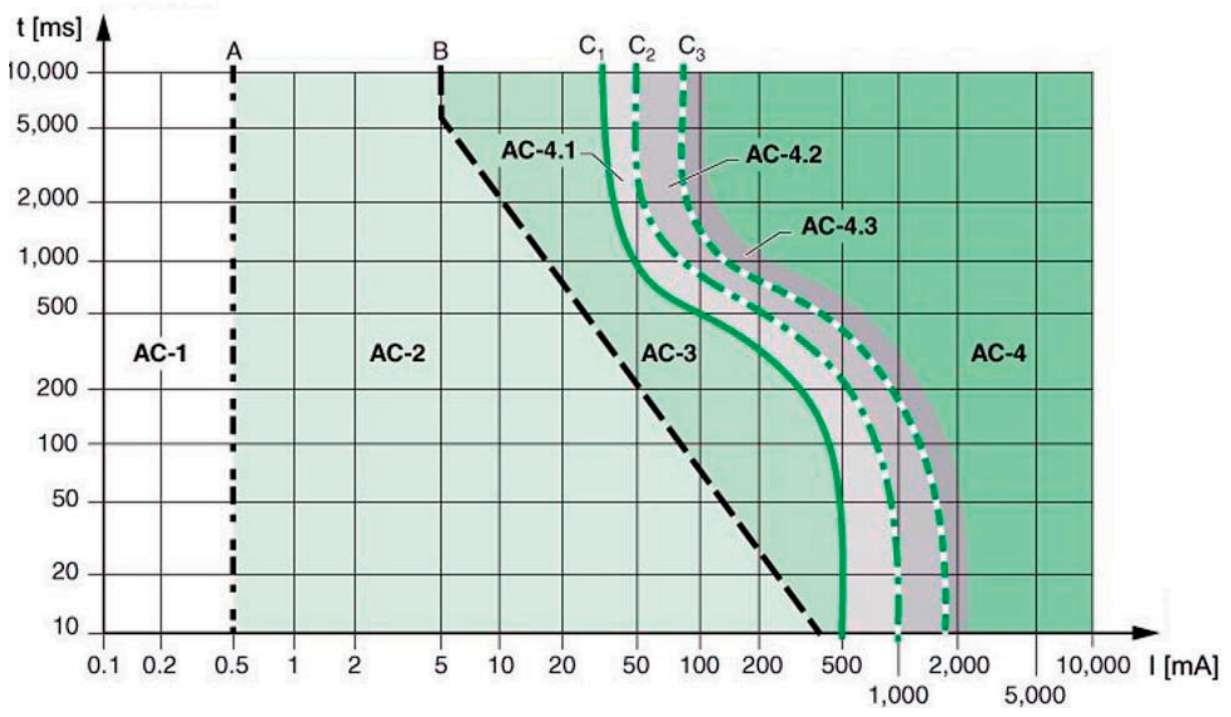

Rys. 1. Charakterystyki oddziaływania prądu przemiennego na organizm człowieka przy przepływie prądu pomiędzy lewą ręką i stopami $[6,7]$

Przy parametrach porażenia wyznaczanych przez obszar AC-1 organizm może „nie zauważyć" przepływu prądu. W obszarze AC 2 wyczuwa się przepływ prądu przy jednoczesnym braku trwałych uszkodzeń. Obszar AC 3 łączy się z wyraźnym oddziaływaniem prądu (skurcze mięśni, trudności z oddychaniem, możliwość wystąpienia migotania komór serca). W obszarze AC-4 można oczekiwać nieodwracalnych skutków przepływu prądu, które najwyraźniej ujawniają się w prawdopodobieństwie wystąpienia migotania komór serca o wartości rzędu 5 \% (poniżej krzywej C2), rzędu 5-50 \% (pomiędzy krzywymi C2 
i C3) oraz powyżej 50 \% (powyżej krzywej C3) [3, 5, 6, 7]. Podawanie wartości z określonym prawdopodobieństwem związane jest ze stochastycznym charakterem reakcji człowieka wynikającym ze zróżnicowania obiektu badawczego, jakim jest organizm ludzki.

Wśród niekorzystnych efektów wynikających z użytkowania energii elektrycznej w sieciach niskiego napięcia można wyróżnić:

- mrowienie,

- skurcze mięśni (wraz z bólem, do poziomu braku możliwości samodzielnego uwolnienia się spod działania prądu);

- zaburzenie i zatrzymanie pracy układu oddechowego;

- zaburzenie i zakłócenia zmysłów wzroku, słuchu, równowagi;

- zakłócenia pracy serca (migotanie komór i zatrzymanie pracy serca);

- oparzenia zewnętrzne i wewnętrzne, spalenia.

Nawet jeśli użytkownik nie znalazł się bezpośrednio pod działaniem prądu rażeniowego, to istnieje możliwość wystąpienia urazów w postaci: oślepienia i poparzenia w wyniku wystąpienia łuku elektrycznego, poparzenia w wyniku pożaru zainicjowanego przez uszkodzenie sieci elektrycznej, urazów mechanicznych wynikających z odruchowej reakcji na hałas, błysk $\mathrm{i}$ inne zjawiska towarzyszące niekontrolowanemu przepływowi prądu.

\section{2. Środki ochrony przeciwporażeniowej w instalacjach NN}

Instalacja elektryczna w postaci, w której spotyka się z nią największa liczba użytkowników, to zespół dobranych elementów elektrycznych o skoordynowanych parametrach technicznych, napięciu znamionowym do $1000 \mathrm{~V}$ prądu przemiennego i $1500 \mathrm{~V}$ prądu stałego, przeznaczonych do doprowadzenia energii elektrycznej z sieci rozdzielczej do odbiorników. Trzy podstawowe funkcje, które powinny być realizowane przez tego typu instalację to:

- dostarczanie energii elektrycznej o wymaganych parametrach technicznych do odbiorników;

- ochrona przed porażeniem prądem elektrycznym, przepięciami, pożarem, wybuchem;

- zabezpieczenie przed szkodliwym oddziaływaniem pola elektromagnetycznego.

Zapewnienie możliwości korzystania z energii elektrycznej z jednoczesnym zapewnieniem wymaganego stopnia bezpieczeństwa regulują między innymi:

- Ustawa z dnia 7 lipca 1994 r. „Prawo Budowlane” - (Dz. U. 2013 poz. 1409, Obwieszczenie Marszałka Sejmu RP z dnia 2 X 2013 r. w sprawie ogłoszenia jednolitego tekstu ustawy - Prawo Budowlane).

- Ustawa z dnia 10 kwietnia 1997 r. "Prawo Energetyczne" - (Dz.U. 2014 poz. 942, Ustawa z dnia 26 VI 2014 r. o zmianie ustawy - Prawo Energetyczne).

- Rozporządzenie Ministra Infrastruktury z dnia 12 kwietnia 2002 r. w sprawie warunków technicznych, jakim powinny odpowiadać budynki i ich usytuowanie (Dz.U. Nr 75, poz.690).

- Rozporządzenie Ministra Gospodarki z dnia 28 marca 2013 r. w sprawie bezpieczeństwa i higieny pracy przy urządzeniach energetycznych (Dz.U 2013. poz. 492).

- Wieloczęściowa Polska Norma 60364 - np. PN-HD 60364-4-41:2009 - Instalacje elektryczne niskiego napięcia.

- Norma N SEP-E-001:2003 - Sieci elektroenergetyczne niskiego napięcia. Ochrona przed porażeniem elektrycznym. 
Najbardziej praktyczne zasady postępowania w przypadku budowy instalacji elektrycznych niskiego napięcia zawierają dwa ostatnie wymienione dokumenty. Zadaniem środków ochrony przeciwporażeniowej jest zabezpieczenie przed negatywnymi skutkami oddziaływania prądu elektrycznego. W odniesieniu do instalacji prądu przemiennego o napięciu do $1 \mathrm{kV}$ oraz prądu stałego o napięciu do $1,5 \mathrm{kV}$, techniczne środki zabezpieczające przed dotykiem bezpośrednim, tj. dotknięciem części przewodzących, które w trakcie normalnej pracy powinny znajdować się pod napięciem, noszą nazwę środków ochrony podstawowej. Środki zabezpieczające przed dotykiem pośrednim, tj. dotknięciem części przewodzących, które mogą znaleźć się pod napięciem w wyniku uszkodzenia urządzenia, noszą nazwę środków ochrony dodatkowej. Środki chroniące w obu wymienionych przypadkach noszą nazwę środków równoczesnej ochrony przed dotykiem bezpośrednim i pośrednim (Rys. 2) [5, 8, 9, 10].

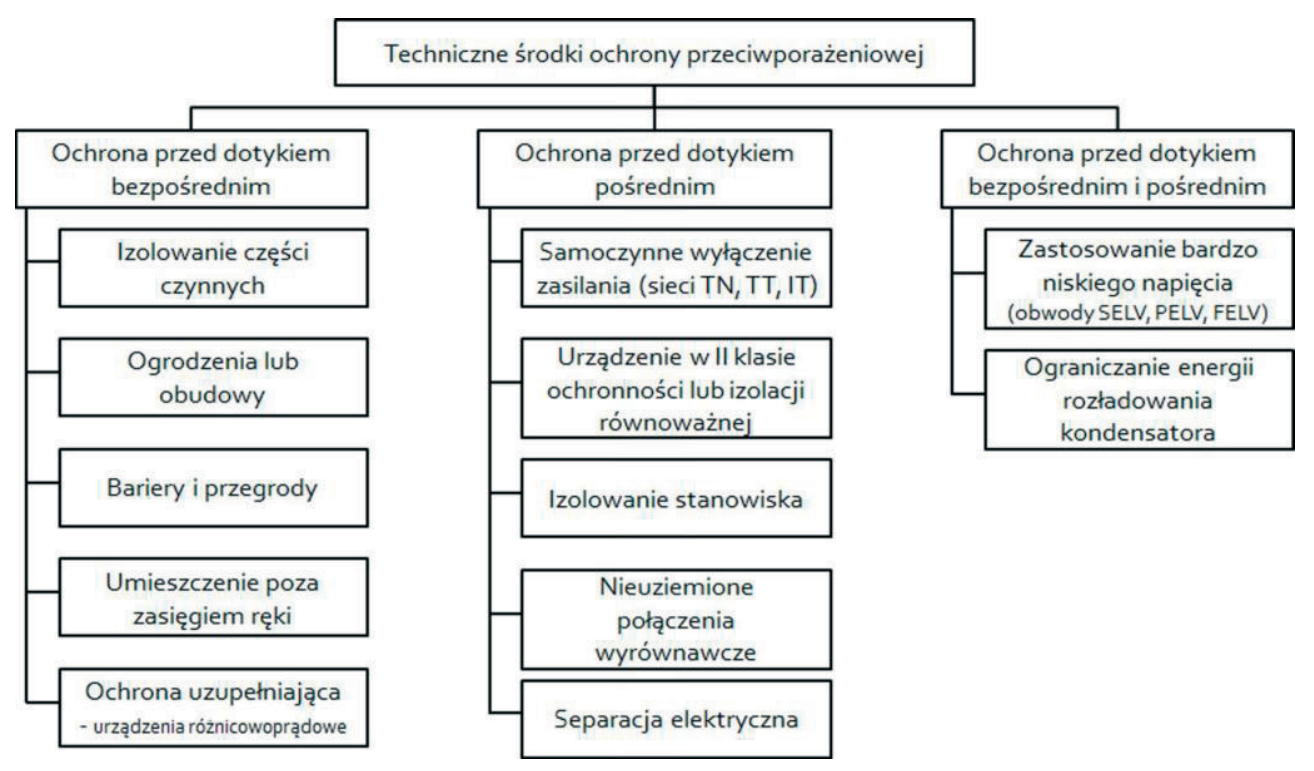

Rys. 2. Klasyfikacja środków ochrony przeciwporażeniowej w sieciach niskiego napięcia [5, 10]

Każdy ze środków zamieszczonych na Rys. 2 ma za zadanie ograniczenie negatywnych skutków oddziaływania prądu zilustrowanych na Rys. 1 poprzez: zapobieganie dotknięciu elementów pod napięciem, stosowanie napięć uniemożliwiających przepływ szkodliwych prądów rażeniowych, ograniczenie wartości prądów rażeniowych, ograniczenie czasu przepływu prądu rażeniowego.

Przedstawiony na Rys. 3 schemat zabezpieczenia odbiornika przez samoczynne wyłączenie zasilania w sieci TT zawiera dwa elementy zabezpieczające przed dotykiem pośrednim - wyłącznik różnicowoprądowy oraz wyłącznik nadprądowy. Ich występowanie wraz ze środkami ochrony przed dotykiem bezpośrednim powinno gwarantować bezpieczne użytkowanie odbiornika. Na obudowie urządzenia nie powinno wstąpić napięcie większe niż $50 \mathrm{~V}$ w odniesieniu do potencjału podłoża. Mimo to zawsze należy brać pod uwagę możliwość wystąpienia uszkodzenia (np. przerwanie przewodu uziemiającego) oraz ingerencję użytkownika w układ (np. tzw. „watowanie zabezpieczeń”, wymianę zabezpieczeń na przypadkowo dobrane), uszkodzenie urządzenia zabezpieczającego odbiornik, a w efekcie możliwość wystąpienia porażenia. 


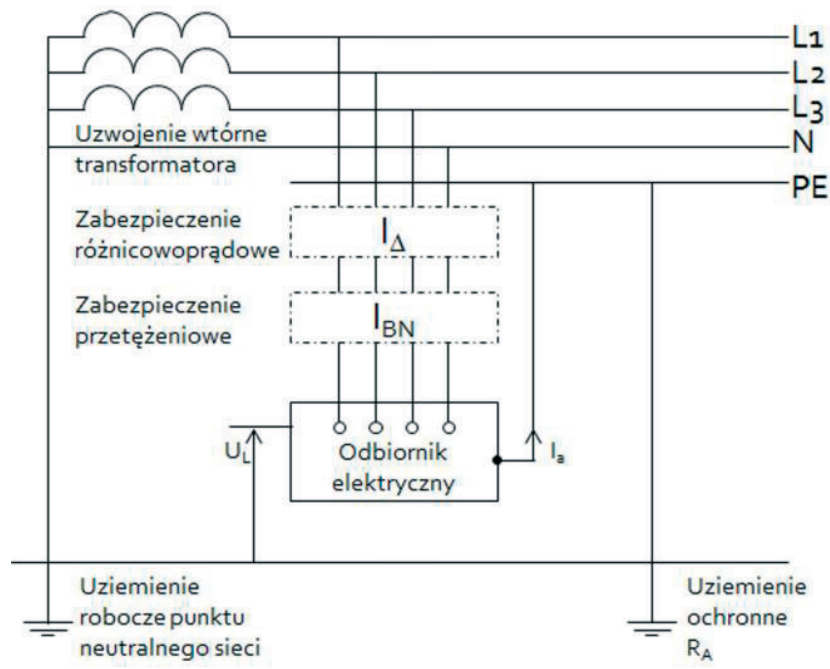

Rys. 3. Ogólny schemat zabezpieczenia odbiornika przez samoczynne wyłączenie zasilania w sieci TT

\section{Wypadki towarzyszące eksploatacji instalacji niskiego napięcia}

Pierwszy zarejestrowany i opisany przypadek porażenia prądem zasilającym urządzenie elektryczne miał miejsce w Niemczech w roku 1887 [1]. W przypadku Polski miarodajnym źródłem informacji na temat wypadków przy pracy, w tym wypadków wskutek użytkowania energii elektrycznej, są publikacje Głównego Urzędu Statystycznego. Na podstawie zestawienia zamieszczonego w tablicy 1 można wnioskować o stopniowym zmniejszaniu się liczby wypadków w latach 2007-2014 (dla roku 2014 dostępne są dane za pierwsze trzy kwartały). Sama liczba wypadków śmiertelnych również wykazuje tendencję opadającą (Rys. 4).

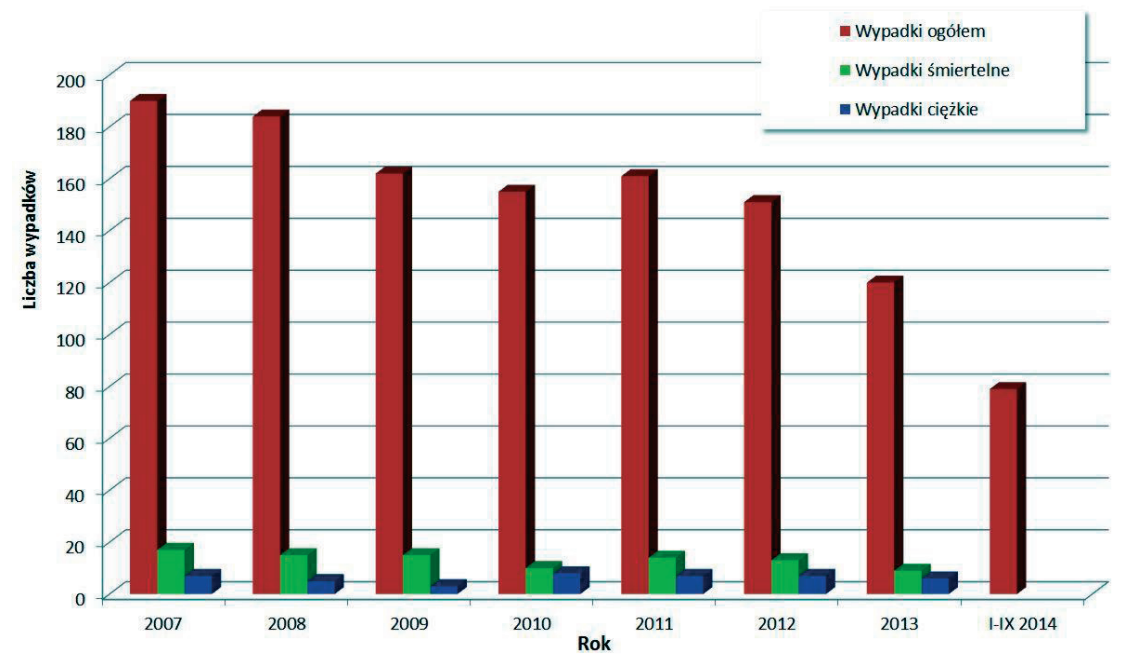

Rys. 4. Liczba wypadków związana z bezpośrednim kontaktem z elektrycznością w latach 2007 - IX 2014 
Tabela 1 . Zestawienie liczby wypadków wywołanych przez dotyk bezpośredni określone na podstawie wydarzeń powodujących uraz wraz z charakterystyką przyczyn ich powstawania [11, 12, 13]

\begin{tabular}{|c|c|c|c|c|c|c|c|c|}
\hline Parametr & 2007 & 2008 & 2009 & 2010 & 2011 & 2012 & 2013 & $\begin{array}{l}\text { I-IX } \\
2014\end{array}$ \\
\hline \multicolumn{9}{|c|}{ Poszkodowani w wypadkach przy pracy wg wydarzeń powodujących uraz } \\
\hline Wypadki ogółem & 190 & 184 & 162 & 155 & 161 & 151 & 120 & 79 \\
\hline Wypadki śmiertelne & 17 & 15 & 15 & 10 & 14 & 13 & 9 & - \\
\hline Wypadki ciężkie & 7 & 5 & 3 & 8 & 7 & 7 & 6 & - \\
\hline \multicolumn{9}{|c|}{ Przyczyny wydarzeń powodujących uraz } \\
\hline Czynnik materialny & 97 & 85 & 82 & 75 & 86 & 82 & 62 & 47 \\
\hline $\begin{array}{l}\text { Błędna organizacja pracy } \\
\text { lub stanowiska }\end{array}$ & 92 & 85 & 69 & 73 & 93 & 60 & 63 & 38 \\
\hline $\begin{array}{l}\text { Błędne posługiwanie się } \\
\text { czynnikiem materialnym }\end{array}$ & 37 & 33 & 21 & 23 & 27 & 23 & 17 & 9 \\
\hline $\begin{array}{l}\text { Nieużywanie sprzętu } \\
\text { ochronnego }\end{array}$ & 14 & 14 & 8 & 11 & 12 & 8 & 14 & 7 \\
\hline $\begin{array}{l}\text { Błędne postępowanie } \\
\text { pracownika }\end{array}$ & 215 & 237 & 207 & 170 & 198 & 212 & 153 & 103 \\
\hline Zły stan psychofizyczny & 4 & 7 & 3 & 7 & 4 & 8 & 2 & 1 \\
\hline Inne & 12 & 10 & 15 & 16 & 10 & 11 & 16 & 6 \\
\hline Przyczyny razem & 471 & 471 & 405 & 375 & 430 & 404 & 327 & 211 \\
\hline
\end{tabular}

Podobnie opadający charakter wykazuje liczba przyczyn, które doprowadziły do wypadków. GUS wprowadza kategoryzację przyczyn wypadków i wyróżnia, takie kategorie jak $[11,12,13,14]$ :

a) wady konstrukcyjne lub niewłaściwe rozwiązanie techniczne i ergonomiczne,

b) niewłaściwe wykonanie,

c) wady materiałowe,

d) niewłaściwa eksploatacja,

e) niewłaściwa organizacja pracy,

f) niewłaściwa organizacja stanowiska pracy,

g) brak lub niewłaściwe posługiwanie się czynnikiem materialnym,

h) nieużywanie sprzętu ochronnego,

i) niewłaściwe samowolne zachowanie pracownika,

j) niewłaściwy stan psychofizyczny pracownika,

k) nieprawidłowe zachowanie się pracownika,

1) inne.

W Tab. 1 dla ułatwienia analizy połączono kategorie a)-d) w kategorię „Czynnik materialny”, kategorie e)-f) w kategorię „Błędna organizacja pracy lub stanowiska” oraz i) i k) w „Błędne postępowanie pracownika”.

Charakter przyczyn wypadków ujawnia się w zestawieniu procentowym zamieszczonym na Rys. 5. W analizowanym okresie wpływ czynnika materialnego pozostaje na stabilnym poziomie oscylującym wokół $20 \%$ przyczyn wypadków. W tym samym okresie wpływ czynnika ludzkiego waha się pomiędzy 45 i 50 \%. Można wnioskować o trwałym, negatywnym wpływie postępowania człowieka na liczbę wypadków wynikających z użytkowania energii elektrycznej. Jeśli źródło przyczyny wypadków z kategorii „Błędna organizacja pracy lub stanowiska” oraz „Nieużywanie sprzętu ochronnego" również przypiszemy czynnikowi ludzkiemu, to wpływ „czynnika ludzkiego” wrośnie do 68-70 \% i zmienia się w podobnym stopniu jak wpływ „czynnika materialnego”. 


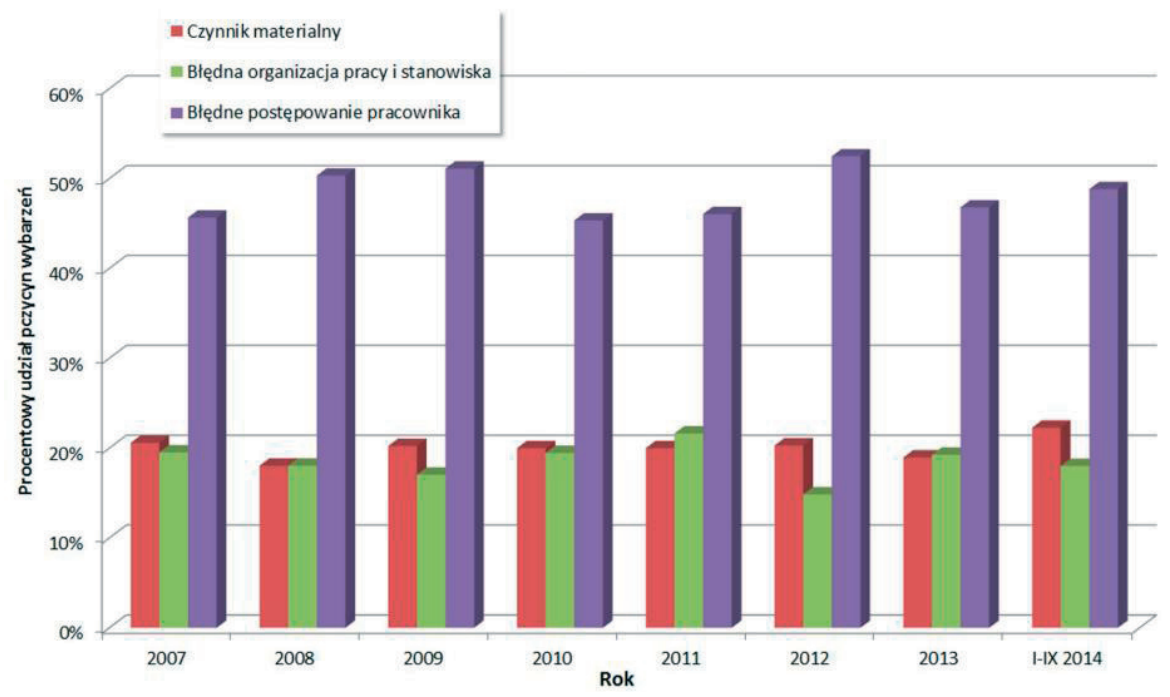

Rys. 5. Procentowy udział przyczyn wydarzeń powodujących uraz w wyniku bezpośredniego kontaktu z elektrycznością w latach 2007- IX 2014

Zwiększenie funkcjonalności telefonów komórkowych polegające na wbudowaniu w praktycznie każdy egzemplarz aparatu fotograficznego lub prostej kamery skutkuje powstawaniem dokumentacji kuriozalnych przypadków użytkowania urządzeń elektrycznych. Możliwość propagowania tego typu dokumentacji w formie statycznej (zdjęcia) i dynamicznej (filmy) w Internecie umożliwia poznanie błędów popełnianych przez użytkowników energii elektrycznej na całym świecie. Zamieszczone dalej fotografie potwierdzają wpływ „czynnika ludzkiego” na potencjalne zaistnienie porażenia. Zastąpienie zabezpieczeń nadmiarowo prądowych z Rys. 6 a) poprzez śruby, spowoduje niekontrolowane działanie zabezpieczeń. Sposób wykonania modyfikacji może wskazywać, że wykonała ją osoba posiadająca podstawowe informacje o sposobie działania bezpieczników topikowych. Samodzielnie wykonany wtyk z Rys. 6 b) nie tylko nie gwarantuje poprawnej pracy urządzenia (możliwość odłączenia w dowolnym momencie), ale dodatkowo obniża poziom zabezpieczenia przeciwporażeniowego i przeciwpożarowego. Podobnego typu ilustracje nonszalanckiego podejścia do użytkowania urządzeń elektrycznych można znaleźć w pracach innych autorów [16].

\section{Podsumowanie}

Analiza wypadków związanych z użytkowaniem energii elektrycznej połączona ze znajomością specyfiki zabezpieczeń instalacji elektrycznych pozwala na postawienie poniższych wniosków.

1. Liczba wypadków przy pracy związanych z użytkowaniem energii elektrycznej oraz ich przyczyn wykazuje w ciągu ostatnich 7 lat minimalny, lecz stabilny spadek. Ta tendencja obserwowana była już w latach wcześniejszych (1987-2009) [17].

2. W zależności od sposobu podejścia, człowieka można obarczyć odpowiedzialnością za 45-50 lub nawet 70 \% wypadków. Wartość ta pozostaje stabilna na przestrzeni analizowanego okresu. 
3. W związku z zaprezentowaną specyfiką przyczyn porażeń, wydaje się, że drogami do obniżenia liczby wypadków może być:

- profilaktyka polegająca na podnoszeniu świadomości użytkowników urządzeń (kursy, egzaminy, uprawnienia, system dodatków motywacyjnych);

- wprowadzanie sprzętu o specyfikacji zgodnej z wymaganiami dla urządzeń o środkach równoczesnej ochrony bezpośredniej i pośredniej.

a)

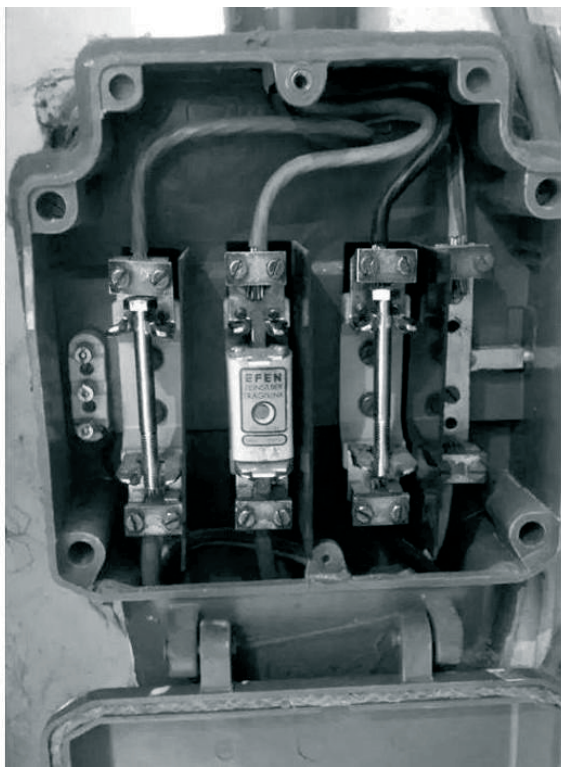

b)

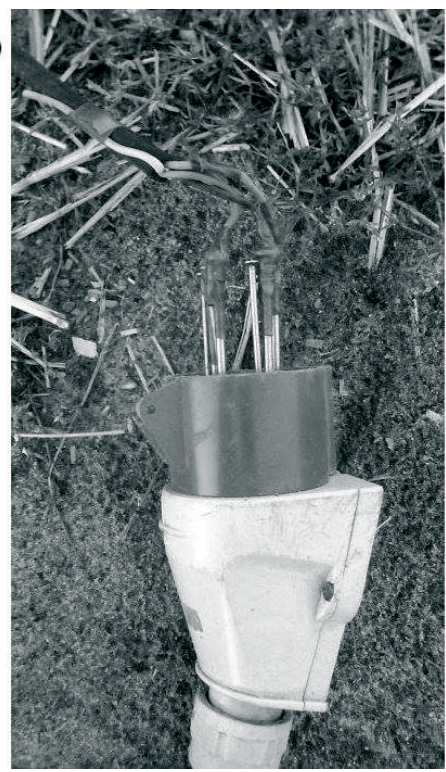

Rys. 6. Przykłady ingerencji w instalację elektryczną obniżające poziom zabezpieczeń przeciwporażeniowych

\section{Literatura}

1. Gierlotka S. Poznanie wpływu pradu elektrycznego na czlowieka. Zeszyty Naukowe Wydziału Elektrotechniki i Automatyki Politechniki Gdańskiej 43 (2015) 147-150.

2. Pasieka D. Dobrodziejstwo pradu, http://rehabilitacja.wieszjak.polki.pl/ rehabilitacjaruchowa/256519,2,Rehabilitacja-pradem.html, 2010-10-08.

3. Nienhaus J., Galle M. Placebo-controlled study of the effects of a standardized MORA bioresonance therapy on functional gastrointestinal complaints. Forsch Komplementmed 13(1) (2006) 28-34

4. Błońska A. Nowa metoda defibrylacji. Migotanie przedsionków. http://www.roik.pl/nowa-metodadefibrylacji-migotanie-przedsionkow/\#more-40525 na podst. Cornell University, 22.07.2011.

5. Lejdy B. Instalacje elektryczne w obiektach budowlanych. Wydawnictwa Naukowo-Techniczne, Warszawa 2009.

6. Niestępski S. Instalacje elektryczne: budowa, projektowanie i eksploatacja, Oficyna Wydawnicza Politechniki Warszawskiej, Warszawa 2011.

7. IEC 60479, TS. Ed. Effects of current on human beings and livestock. Part 1: General aspects. IEC TS 60479-1:2005/COR2:2013, 11.06.2013.

8. Boczkowski A. Ochrona przeciwporażeniowa w instalacjach. Wydawnictwo Wiedza i Praktyka, Warszawa 2014.

9. Jabłoński W. Ochrona przeciwporażeniowa w urzadzeniach elektroenergetycznych niskiego $i$ wysokiego napięcia. WNT, Warszawa 2006.

10. Markiewicz H. Instalacje elektryczne. WNT, Warszawa 2008. 
11. Główny Urząd Statystyczny, Departament Pracy i Warunków Życia. Wypadki przy pracy w 2007 r. Warszawa 2008; Wypadki przy pracy w 2008 r. Warszawa 2009.

12. Główny Urząd Statystyczny, Departament Pracy. Wypadki przy pracy w 2009 r. Warszawa 2010; Wypadki przy pracy w $2010 \mathrm{r}$. Warszawa 2011.

13. Główny Urząd Statystyczny, Departament Badań Demograficznych i Rynku Pracy. Wypadki przy pracy w 2011 r. Warszawa 2012; Wypadki przy pracy w 2012 r. Warszawa 2013; Wypadki przy pracy w 2013 r. Warszawa 2014, Wypadki przy pracy w okresie I-III 2014 r. Warszawa 2014.

14. Jasiński W. Przyczyny porażeń pradem elektrycznym. Elektro Info, 9 (2013) 58-62.

15. Wiśniewska A.M., Wiśniewski W. Rażeni prądem. Promotor 10 (2014).

16. Danielski L., Danielski P. Dane statystyczne o śmiertelnych wypadkach porażeń pradem elektrycznym w Polsce w latach 2005-2009. INPE nr 146-147, 2011.

\title{
The human factor and the effectiveness of protection against electric shock of users of electrical energy in buildings
}

\author{
Andrzej Sumorek \\ Department of Structural Mechanics, Faculty of Civil Engineering and Architecture, \\ Lublin University of Technology, e-mail: a.sumorek@pollub.pl
}

\begin{abstract}
Paper presents measures of protection against electric shock in low-voltage electrical systems in the aspect of their ineffectiveness in relation to selected situations. The first part of the article describes reasons for preventing the flow of electric current through the human body. Simultaneously it is described methods of preventing of negative effects of electrical current on electrical devices users in installations with voltage up to $1 \mathrm{kV}$. The final part of the paper contains a list of cases in which the protection measures are ineffective. It is also included an analysis of the causes of accidents.

Keywords: protection against electric shock, electrical installation, industrial accidents.
\end{abstract}


